\title{
Takaysu arteritis treatment in children
}

\author{
YO Kostina*, GA Lyskina \\ From 21st European Pediatric Rheumatology (PReS) Congress \\ Belgrade, Serbia. 17-21 September 2014
}

\section{Introduction}

Takayasu arteritis (TA) is a rare chronic inflammatory disease of unknown origin mainly involving the large vessels, such as the aorta and its primary branches. There is no uniform strategy of therapy TA in children owing to a rarity of this pathology and no specificity of clinic.

\section{Objectives}

Efficacy of 3 treatment regiments (TR) was retrospectively analysed in 38 children with TA aged from 3 till 16 years. Follow up period was 36 mo. In 27 of 38 patients diagnosis was established after a year from emergence of the first symptoms and characterized by widespread inflammation in the aorta and its main branches.

\section{Methods}

Group 1 (36 patients) received the combined therapy by glucocorticoids (Pr) and methotrexate (MTX). Cyclophosphamide $(\mathrm{CYC})$ used at 2 patients as first therapy with widespread inflammation and in 6 - at inefficiency of primary treatment of MTX (group 2). In 5 children with refractory TA - infliximab (INF) (group 3). TR efficacy was estimated by TA activity index (AI), based on Birmingham scale of vasculitis activity (erythrocyte sedimentation rate (ESR), C-reactive protein (CRP), clinical symptoms and results of Doppler ultrasound, etc.).

\section{Results}

1 TR was effective in $67 \%$ patients, 2 TR show reliable decrease in an index of activity in 6 months, remission is noted in 12 months therapy. The success of 3 months INF treatment was evaluated according to the normal significances of ESR, CRP and lack of active disease symptoms, after 6 months - reduced of vessel wall thickness.

\footnotetext{
Pediactrics, I.M. Sechenov First Moscow State Medical University, Moscow,
} Russian Federation

(c) 2014 Kostina and Lyskina; licensee BioMed Central Ltd. This is an Open Access article distributed under the terms of the Creative
Cite this article as: Kostina and Lyskina: Takaysu arteritis treatment in children. Pediatric Rheumatology 2014 12(Suppl 1):P355.

Submit your next manuscript to BioMed Central and take full advantage of:

- Convenient online submission

- Thorough peer review

- No space constraints or color figure charges

- Immediate publication on acceptance

- Inclusion in PubMed, CAS, Scopus and Google Scholar

- Research which is freely available for redistribution Submit your manuscript at
www.biomedcentral.com/submit C BioMed Central 